\title{
Folate intake, alcohol consumption, and the methylenetetrahydrofolate reductase (MTHFR) C677T gene polymorphism: influence on prostate cancer risk and interactions
}

\author{
Lindsay C. Kobayashi ${ }^{1,2}$, Heather Limburg ${ }^{1+}$, Qun Miao ${ }^{1,2}$, Christy Woolcott ${ }^{3}$, Leanne L. Bedard ${ }^{4}$, \\ Thomas E. Massey ${ }^{4}$ and Kristan J. Aronson ${ }^{1,2 *}$ \\ ${ }^{1}$ Department of Community Health and Epidemiology, Queen's University, Kingston, ON, Canada \\ 2 Division of Cancer Care and Epidemiology, Queen's Cancer Research Institute, Queen's University, Kingston, ON, Canada \\ ${ }^{3}$ Perinatal Epidemiology Research Unit, Departments of Obstetrics and Gynecology and Pediatrics, Dalhousie University, Halifax, NS, Canada \\ ${ }^{4}$ Pharmacology and Toxicology Graduate Program, Department of Biomedical and Molecular Sciences, Queen's University, Kingston, ON, Canada
}

Edited by:

Yawei Zhang, Yale University, USA

Reviewed by:

Yanwen Chen, Case Western

Reserve University, USA

Stella Koutros, National Cancer

Institute, USA

*Correspondence:

Kristan J. Aronson, Division of

Cancer Care and Epidemiology,

Department of Community Health

and Epidemiology, Queen's Cancer

Research Institute, Queen's

University, 10 Stuart St., level 2,

Kingston, ON K7L 3N6, Canada.

e-mail:aronson@queensu.ca

${ }^{\dagger}$ Former affiliation.
Purpose: Folate is essential to DNA methylation and synthesis and may have a complex dualistic role in prostate cancer. Alcohol use may increase risk and epigenetic factors may interact with lifestyle exposures. We aimed to characterize the independent and joint effects of folate intake, alcohol consumption, and the MTHFR C677T gene polymorphism on prostate cancer risk, while accounting for intakes of vitamins $B_{2}, B_{6}$, $B_{12}$, methionine, total energy, and confounders. Methods: A case-control study was conducted at Kingston General Hospital of 80 incident primary prostate cancer cases and 334 urology clinic controls, all with normal age-specific PSA levels (to exclude latent prostate cancers). Participants completed a questionnaire on folate and alcohol intakes and potential confounders prior to knowledge of diagnosis, eliminating recall bias, and blood was drawn for MTHFR genotyping. Joint effects of exposures were assessed using unconditional logistic regression and significance of multiplicative and additive interactions using general linear models. Results: Folate, vitamins $B_{2}, B_{6}$, $\mathrm{B}_{12}$, methionine, and the CT and TT genotypes were not associated with prostate cancer risk. The highest tertile of lifetime alcohol consumption was associated with increased risk $(\mathrm{OR}=2.08 ; 95 \% \mathrm{Cl}: 1.12-3.86)$. Consumption of $>5$ alcoholic drinks per week was associated with increased prostate cancer risk among men with low folate intake $(\mathrm{OR}=2.38 ; 95 \% \mathrm{Cl}: 1.01-5.57)$, and higher risk among those with the CC MTHFR genotype (OR $=4.43 ; 95 \% \mathrm{Cl}: 1.15-17.05)$. Increased risk was also apparent for average weekly alcohol consumption when accounting for the multiplicative interaction between folate intake and MTHFR C677T genotype (OR $=3.22 ; 95 \% \mathrm{Cl}: 1.36-7.59$ ). Conclusion: Alcohol consumption is associated with increased prostate cancer risk, and this association is stronger among men with low folate intake, with the CC MTHFR genotype, and when accounting for the joint effect of folate intake and MTHFR C677T genotype.

Keywords: prostate cancer, folate, alcohol, genetic variants, carbon metabolism, gene-environment interactions, case-control study, male health

\section{INTRODUCTION}

Prostate cancer is the second most common malignancy among men (Ferlay et al., 2010). With 5-10\% attributable to family history and genetic susceptibility (National Cancer Institute, 2004), etiology of prostate cancer is largely unknown (International Agency for Research on Cancer, 2008). One dietary factor with a complex relationship with prostate cancer is folate, a watersoluble B vitamin that provides substrates for DNA methylation and synthesis of purines and thymidine (Kim, 1999; Fairfield and Fletcher, 2002). Biologic plausibility exists for the contribution of both high and low folate intakes to prostate carcinogenesis. Deficient folate levels have been shown in murine prostate cancer models to result in $\mathrm{CpG}$ island hypermethylation and misincorporation of uracil into DNA strands, leading to genetic and epigenetic instability that is characteristic of carcinogenesis (Bistulfi et al., 2010). Conversely, folate deficiency can halt progression of pre-existing tumors in the murine model (Tomaszewski et al., 2011) and high serum folate concentrations have been associated with an increased rate of progression among men with existing prostate cancer (Collin et al., 2010a). Conflicting results from epidemiological research may reflect this potential dualistic role of folate in prostate carcinogenesis (Vlajinac et al., 1997; Weinstein et al., 2003; Hultdin et al., 2005; Pelucchi et al., 2005; Rossi et al., 2006; Stevens et al., 2006; 
Johansson et al., 2008; Figueiredo et al., 2009; Shannon et al., 2009; Zhang et al., 2009; Beilby et al., 2010; Collin et al., 2010a,b). Understanding of the true effects of folate intake on prostate carcinogenesis is warranted to inform dietary recommendations, especially in the context where many countries have implemented fortification of several foods with folate (Lucock and Yates, 2009).

The effects of folate may be moderated by two potential independent risk factors for prostate cancer: alcohol consumption, and the C677T polymorphism of the methylenetetrahydrofolate reductase (MTHFR) gene. A meta-analysis in 2009 showed that consistently heavy alcohol drinking confers higher risk for prostate cancer (Middleton Fillmore et al., 2009). Alcohol directly interferes with the actions of folate in the body by inhibiting its absorption in the small intestine (Dennis, 2000). Heavier drinkers thus have a greater need for folate, which may place them at higher risk for prostate cancer. While some previous epidemiological studies on prostate cancer have controlled for alcohol as a confounding factor, only four have assessed an interaction between folate intake and alcohol consumption, and these have had yielded conflicting results (Weinstein et al., 2003; Pelucchi et al., 2005; Stevens et al., 2006; Shannon et al., 2009).

The MTHFR gene encodes the MTHFR enzyme that plays an essential role in folate metabolism by catalyzing the production of 5-methyltetrahydrofolate, the main circulating form of folate required for DNA methylation (Lathrop Stern et al., 2000). The C677T (cytosine-to-thymine) mutation of the MTHFR gene, CC in wildtype, can produce the heterozygous CT gene variant or the homozygous TT variant: the CT variant occurs in $50 \%$ of the population and results in $65 \%$ of the wildtype enzyme's functional activity, while the TT variant occurs in approximately $10 \%$ of the population and results in 30\% functional enzymatic activity (Frosst et al., 1995; Lathrop Stern et al., 2000). The MTHFR C677T polymorphism has not been identified in recent genome-wide association studies as associated with susceptibility for prostate cancer (Thomas et al., 2008; Collin et al., 2009; Kote-Jarai et al., 2011; Schumacher et al., 2011). However, it may be relevant when examined in conjunction with folate and alcohol intakes to help explain prostate cancer risk not attributable to susceptibility genes alone. Epidemiological studies have reported associations between the TT variant genotype and reduced risks of colorectal (Tiaoli et al., 2009) and breast (Qi et al., 2010) cancers, while findings regarding prostate cancer conflict (Bai et al., 2009; Collin et al., 2009; Cai et al., 2010). A simulation study supports a role for folate-MTHFR genotype interaction in carcinogenesis, showing reduced DNA methylation rates when low MTHFR gene activity is combined with high intracellular folate concentrations (Neuhouser et al., 2011). One epidemiological study to date has considered this interaction in prostate cancer, indicating an increased risk associated with high folate intake among men with the TT MTHFR genotype (Van Guelpen et al., 2006). To our knowledge, no previous study has examined the interaction between alcohol and MTHFR genotype in prostate cancer etiology. We sought to assess the potential independent and joint associations of folate intake, alcohol consumption, and the C677T MTHFR gene polymorphism with prostate cancer risk.

\section{MATERIALS AND METHODS OVERVIEW}

A case-control study was conducted where eligible men aged 50-80 years were recruited from Kingston General Hospital in Kingston, ON, Canada from 1997 to 1999. Eligible participants were either scheduled for prostate core biopsy or were visiting the urology clinic for other reasons and had normal agespecific prostate specific antigen (PSA) levels $(\leq 3.5$ in $50-60$ age group, $\leq 4.5$ in $60-70$ age group, and $\leq 6.5$ in $70-80$ age group) and a normal digital rectal examination (DRE). Of 1288 men seen in clinic, 746 did not meet these criteria. Of the 542 eligible subjects, $71(13 \%)$ were excluded due to diagnosis of prostate intraepithelial neoplasia, use of a hormonal medication, or missing questionnaire, and 56 declined to participate (10\%). Participants were 414 men (76\%) enrolled prior to knowledge of diagnosis who completed a questionnaire regarding demographic, lifestyle, medical, diet and occupational histories, and donated $15 \mathrm{~mL}$ of blood. After biopsy and pathology exams for 214 eligible biopsy subjects, 80 were diagnosed as incident primary prostate cancer cases, and the other 134 were included as "biopsy controls." In addition, 200 eligible cancer-free men of the same age distribution who were diagnosed with a noncancer urologic condition were enrolled as "urology controls," for a total of 334 controls. Among these groups, 43 cases (54\%), 102 biopsy controls (76\%), and 68 urology controls (34\%) consented to MTHFR genotype analysis. This study was approved by the Human Ethics Research Board at Queen's University and Kingston General Hospital.

\section{DIETARY NUTRIENT ASSESSMENT}

The dietary section of the questionnaire was adapted from Byers and colleagues' food frequency questionnaire (Byers et al., 1985) and requested information about intake of 62 food items in the time period two years prior to interview. These food items accounted for the majority of vitamin, fiber, fat, protein, and caloric intakes, and the reproducibility and validity of a similar questionnaire has been verified (Willett et al., 1988). Participants were also asked about vitamin or mineral supplements containing folate taken for six months or more. Results concerning prostate cancer risk associated with dietary patterns and organochlorine exposures were published previously (Walker et al., 2005; Aronson et al., 2010).

Reported food intakes were converted to average consumption per day and dietary nutrient levels were determined based on the average portion size, as described in Canada's Food Guide. Folate was the primary nutrient of interest, while vitamins $B_{2}$ (riboflavin), $B_{6}$, and $B_{12}$, fat, energy, and methionine levels were calculated due to their possible roles as confounding factors. Specifically, food nutrient levels were determined using the 1991 Canadian Nutrient file (Nutrition Research Division, and Health Canada, 2001). Folic acid obtained from fortified grain products was not included since mandatory fortification did not start in Canada until 1998 and our data refer to prior to that year. Calculations of methionine content were based on the 2007 Canadian Nutrient file (Nutrition Research Division, and Health Canada, 2007) since the 1991 version did not contain these measurements. Data from the 2007 and 1991 Canadian 
Nutrient files were in agreement (excluding fortified grains) for most categories.

For categories containing more than one food item (e.g. "orange or grapefruit juice"), the Canada Food Statistics 1996 (Agriculture and Agri-Food Canada, and Statistics Canada, 2010) and the Canadian Food Value Chain Bureau Retail Sales data in 1996 (Agriculture and Agri-Food Canada, Food Value Chain Bureau, 2004) were used to estimate the average consumption of each food item within a food category (e.g., orange juice was weighted as $93 \%$ and grapefruit juice as $7 \%$ of the total nutrient value of "orange and grapefruit juice," based on the average purchases of each item). The unstable nature of folate when cooked or heated was accounted for in the analysis since food preparation techniques impact nutrient levels. All components used to determine the nutrient values for the 62 food items are available upon request. Total nutrient levels were calculated for each individual based on their average consumption, and nutrient levels were adjusted to account for total caloric intake (Willett, 1998).

\section{ALCOHOL CONSUMPTION ASSESSMENT}

Alcohol consumption was defined as one alcoholic drink $=12$ $\mathrm{oz}$ of beer, $4 \mathrm{oz}$ of wine, or $1.5 \mathrm{oz}$ of liquor. Alcohol exposure variables were: age started drinking, years drinking, average total alcohol per week two years prior to study entry, average weekly consumption of beer, wine, and liquor separately two years prior to study entry, and lifetime alcohol intake.

\section{MTHFR C677T POLYMORPHISM ANALYSIS}

Blood samples were stored at $-80^{\circ} \mathrm{C}$ and were defrosted to room temperature for analysis. DNA isolation was performed using the QIAamp DNA Blood Mini Kit spin protocol (Qiagen, Valencia, CA), and PCR-RFLP analysis was based on methods described previously (Frosst et al., 1995; ElSammak et al., 2004). Primers corresponding to the C677T site of the MTHFR gene had the exonic sequence of $5^{\prime}$ TGAAGGAGAAGGTGTCTGCGGGA- $3^{\prime}$ and the intronic sequence of 5'-AGGACGGTGCGGTGAGAGTG-3'. The MTHFR C667T polymorphism was identified using the Hinfl enzyme (Promega), which cleaves the DNA when the variant allele is present. The wildtype CC fragment showed a 198 base pair (bp) fragment when analysed by gel electrophoresis. The cleaved homozygous TT variant showed two fragments of 175 and $23 \mathrm{bp}$. The cleaved heterozygous CT variant produced three fragments of 198, 175, and 23 bp. To ensure quality control, PCR-RFLP results for a subset of gene fragments were verified against exact nucleotide sequences for these fragments, as sequenced by Cortec DNA Service Laboratories (Kingston, ON).

\section{STATISTICAL ANALYSIS}

Independent associations between folate intake, alcohol consumption, and MTHFR C677T genotype and risk of prostate cancer were estimated using unconditional logistic regression, with age included in all models. Folate intake was adjusted for energy intake, and was analysed continuously (per $100 \mu \mathrm{g} /$ day), as tertiles based on intake among controls, and as ever use of a vitamin or mineral supplement containing folate for $\geq 6$ months (yes/no). Intakes of vitamins $\mathrm{B}_{2}, \mathrm{~B}_{6}$, and $\mathrm{B}_{12}$, and methionine were each analysed in these ways. Folate intake was also examined by Gleason score among cases, stratified into highly (score $\geq 7$ ) and less aggressive (score 5-6) groups. Alcohol consumption was analysed as age started drinking, total alcohol intake per week ( $>5$ drinks vs. $\leq 5)$, total beer, wine, and liquor per week (1-7 drinks and $\geq 8$ drinks vs. $<1$ drink), and total lifetime alcohol intake (continuous per 1000 drinks, and as tertiles based on distribution among controls). Analyses of alcohol variables were performed excluding never drinkers $(n=68$ cases and 292 controls included). MTHFR genotype was analysed with risk of the CT (heterozygous mutant) and TT genotypes (homozygous mutant) compared with the CC genotype (wildtype), both individually and combined as $\mathrm{CT}+\mathrm{TT}$ in a dominant genetic model (Lewis, 2002). Potential confounders in addition to age were selected using a backward change-in-estimate $(\geq 10 \%)$ method (Rothman and Greenland, 1998).

The joint effects of folate intake, alcohol consumption, and MTHFR genotype were estimated using unconditional logistic regression models adjusted for the same covariates as the main effect models, with combinations of low folate intake, low alcohol consumption, and the CC MTHFR genotype as the common reference groups. Low folate consumption was defined as $\leq 214.03 \mu$ g per day (with $>214.03$ defined as high), and low alcohol consumption was defined as $\leq 5$ drinks per week (with $>5$ defined as high). Statistical significance of multiplicative and additive interactions was assessed from the likelihood ratio tests performed using the GENMOD procedure in SAS, which allows testing of these two types of interactions separately in general linear models (Littell et al., 2002). Analyses of interactions involving MTHFR genotype were performed using a dominant genetic model where the CT and TT genotypes were combined and compared to the CC genotype, as too few cases and controls displayed the TT genotype to use an additive gene model (Lewis, 2002).

Sensitivity analyses compared cases to a sub-group of controls excluding biopsy controls, and separately to controls excluding those with benign prostatic hyperplasia. Statistical analyses were performed using SAS (Version 9.2, SAS Institute, Cary, NC).

\section{RESULTS}

While most characteristics of cases and controls were similar (Table 1), controls had more cumulative smoking exposure and cases were more likely than controls to report strenuous physical activity as a teen. In terms of the exposures of interest, cases started drinking alcohol at a younger mean age ( 18 years old) than controls (almost 20 years old), and consumed more total alcohol per week on average than controls (Table 2). Consumption of folate was similar between cases and controls (Table 2). Consumption of vitamins $\mathrm{B}_{2}, \mathrm{~B}_{6}, \mathrm{~B}_{12}$, and methionine was similar (not shown).

No association with prostate cancer risk was apparent for dietary folate analysed continuously, by tertile, or according supplement use as the source, nor for vitamins $\mathrm{B}_{2}, \mathrm{~B}_{6}, \mathrm{~B}_{12}$, or methionine (folate only shown in Table 2 ). When cases were stratified by Gleason score, $57 \%$ had a score $\geq 7$, and $43 \%$ had a score 5-6. Of those with Gleason score $\geq 7,32 \%$ were in the lowest tertile of folate intake, while $12 \%$ with a score of 5-6 were 
Table 1 | Characteristics of study participants, $n=414$ (80 cases; 334 controls).

\begin{tabular}{|c|c|c|c|}
\hline Characteristics & Cases $n(\%)$ & Controls $n(\%)$ & $p$-value \\
\hline $\begin{array}{l}\text { Age (years), mean } \\
\pm \mathrm{SD}\end{array}$ & $65.1 \pm 6.0$ & $63.6 \pm 6.9$ & 0.08 \\
\hline \multicolumn{4}{|l|}{ GLEASON SCORE } \\
\hline 5 & $3(4)$ & - & - \\
\hline 6 & $30(38)$ & - & - \\
\hline 7 & $25(31)$ & - & - \\
\hline 8 & $11(14)$ & - & - \\
\hline 9 & $8(10)$ & - & - \\
\hline Missing & $3(4)$ & - & - \\
\hline \multicolumn{4}{|l|}{ MARITAL STATUS } \\
\hline Married & $73(91)$ & $286(86)$ & 0.18 \\
\hline Other & $7(9)$ & $48(14)$ & - \\
\hline \multicolumn{4}{|l|}{ ANCESTRY } \\
\hline British & $59(74)$ & $230(70)$ & 0.48 \\
\hline Other & $21(26)$ & $100(30)$ & - \\
\hline \multicolumn{4}{|l|}{ EDUCATION } \\
\hline Secondary or less & 39 (49) & $160(48)$ & 0.91 \\
\hline Post- secondary & $41(51)$ & $173(52)$ & - \\
\hline \multicolumn{4}{|l|}{ PERSONAL INCOME } \\
\hline Low & $43(54)$ & $190(57)$ & 0.61 \\
\hline High & $37(46)$ & $144(43)$ & - \\
\hline \multicolumn{4}{|c|}{ BMI AT AGE 40 YEARS $\left(\mathrm{kg} / \mathrm{m}^{2}\right)$} \\
\hline Mean \pm SD & $24.5 \pm 0.3$ & $25.0 \pm 3.1$ & 0.28 \\
\hline$<23.68$ & $29(36)$ & $113(33)$ & $0.64^{*}$ \\
\hline $23.69-25.88$ & $29(36)$ & $111(33)$ & - \\
\hline$>25.88$ & $22(28)$ & $110(33)$ & - \\
\hline \multicolumn{4}{|c|}{ CURRENT SMOKING STATUS } \\
\hline No & $65(81)$ & $293(88)$ & 0.13 \\
\hline Yes & 15 (19) & $41(12)$ & - \\
\hline $\begin{array}{l}\text { Lifetime smoking } \\
\text { pack-years among } \\
\text { ever smokers, mean } \\
\pm \text { SD }\end{array}$ & $30.6 \pm 1.7$ & $43.0 \pm 6.1$ & 0.06 \\
\hline \multicolumn{4}{|c|}{ FIRST-DEGREE FAMILY HISTORY OF PROSTATE CANCER } \\
\hline No & $61(86)$ & $270(85)$ & 0.87 \\
\hline Yes & $10(14)$ & $47(15)$ & - \\
\hline \multicolumn{4}{|c|}{ FIRST-DEGREE FAMILY BREAST CANCER HISTORY } \\
\hline No & $70(91)$ & $279(87)$ & 0.40 \\
\hline Yes & $7(9)$ & $40(13)$ & - \\
\hline \multicolumn{4}{|c|}{ PHYSICAL ACTIVITY AS A TEEN } \\
\hline Little & $20(25)$ & $133(40)$ & 0.012 \\
\hline Moderate & 39 (49) & $150(45)$ & - \\
\hline Strenuous & $21(26)$ & $50(15)$ & - \\
\hline \multicolumn{4}{|l|}{ VASECTOMY } \\
\hline No & $58(72.5)$ & $240(72)$ & 0.90 \\
\hline Yes & $22(27.5)$ & $94(28)$ & - \\
\hline
\end{tabular}

* $p$ for trend.

$p$-values $<0.05$ were considered statistically significant.

in the lowest tertile, indicating lower folate with more prostate cancer progression $(p$-trend $=0.06)$.

In terms of alcohol consumption, also seen in Table 2, the highest tertile of lifetime total alcohol intake was associated with a doubling in prostate cancer risk $(\mathrm{OR}=2.08 ; 95 \% \mathrm{CI}: 1.12-3.86)$. Average weekly total alcohol consumption of greater than five drinks per week was associated with increased prostate cancer risk $(\mathrm{OR}=1.75$; 95\% CI: 1.00-3.06). When further adjusted for folate intake, MTHFR C677T genotype, and the multiplicative interaction between the two, the magnitude of risk was even higher $(\mathrm{OR}=3.22$; 95\% CI: $1.36-7.59)$.

In terms of MTHFR C677T genotype among consenting cases, $44 \%$ displayed the CT genotype, 5\% displayed the TT genotype, and $51 \%$ displayed with wildtype CC genotype. Among genotyped controls, these numbers were 51,7 , and $42 \%$, respectively. The CT and TT MTHFR genotypes were not associated with prostate cancer risk (Table 2 ).

Folate intake and alcohol consumption considered together are shown in Table 3. Combined high alcohol and low folate intakes were associated with increased prostate cancer risk $(\mathrm{OR}=2.38$; 95\% CI: 1.01-5.57), although the interaction was not significant under multiplicative or additive models (Table 3). No multiplicative or additive effects of MTHFR genotype and folate intake were observed (Table 4). When the MTHFR genotype and alcohol consumption were investigated together, the OR for $>5$ compared to $\leq 5$ drinks per week was 4.43 (95\% CI: 1.15-17.05) within the CC genotype (Table 5). Sensitivity analyses comparing cases to controls excluding biopsy controls, and separately to controls not diagnosed with benign prostatic hyperplasia, found results similar to the overall analysis.

\section{DISCUSSION}

In this study of incident primary prostate cancer cases and clinicbased controls, all of whom were men with normal PSA and DRE results, independent effects of folate intake and MTHFR genotype on prostate cancer risk were not observed. We did observe that total lifetime alcohol consumption increased prostate cancer risk two-fold among men in the highest consumption tertile. Further, consumption of more than five alcoholic drinks per week increased prostate risk over two-fold among men with low folate intake and over four-fold among men with the CC genotype. Average weekly alcohol consumption was also associated with increased prostate cancer risk when folate intake, MTHFR C677T genotype, and their multiplicative interaction were accounted for. We observed no gene-environment interaction between the MTHFR C677T polymorphism and folate intake.

Our findings for the effects of folate intake on prostate cancer risk are consistent with five case-control studies (Vlajinac et al., 1997; Weinstein et al., 2003; Johansson et al., 2008; Zhang et al., 2009; Collin et al., 2010b) and three cohort studies (Stevens et al., 2006; Weinstein et al., 2006; Beilby et al., 2010). Our results are inconsistent with two case-control studies reporting decreased risk with higher dietary folate intake (Pelucchi et al., 2005; Shannon et al., 2009), and a prospective study and randomized clinical trial both finding increased risk with higher intakes (Hultdin et al., 2005; Figueiredo et al., 2009). Inconsistent findings from existing studies may be in part due to failure to take interactions and stage and/or grade of prostate cancer at diagnosis into account. Increasing evidence supports a dual role for folate intake in prostate carcinogenesis 
Table 2 | Associations between folate intake, alcohol consumption, the MTHFR C677T polymorphism, and prostate cancer risk, $n=414$ (80 cases; 334 controls).

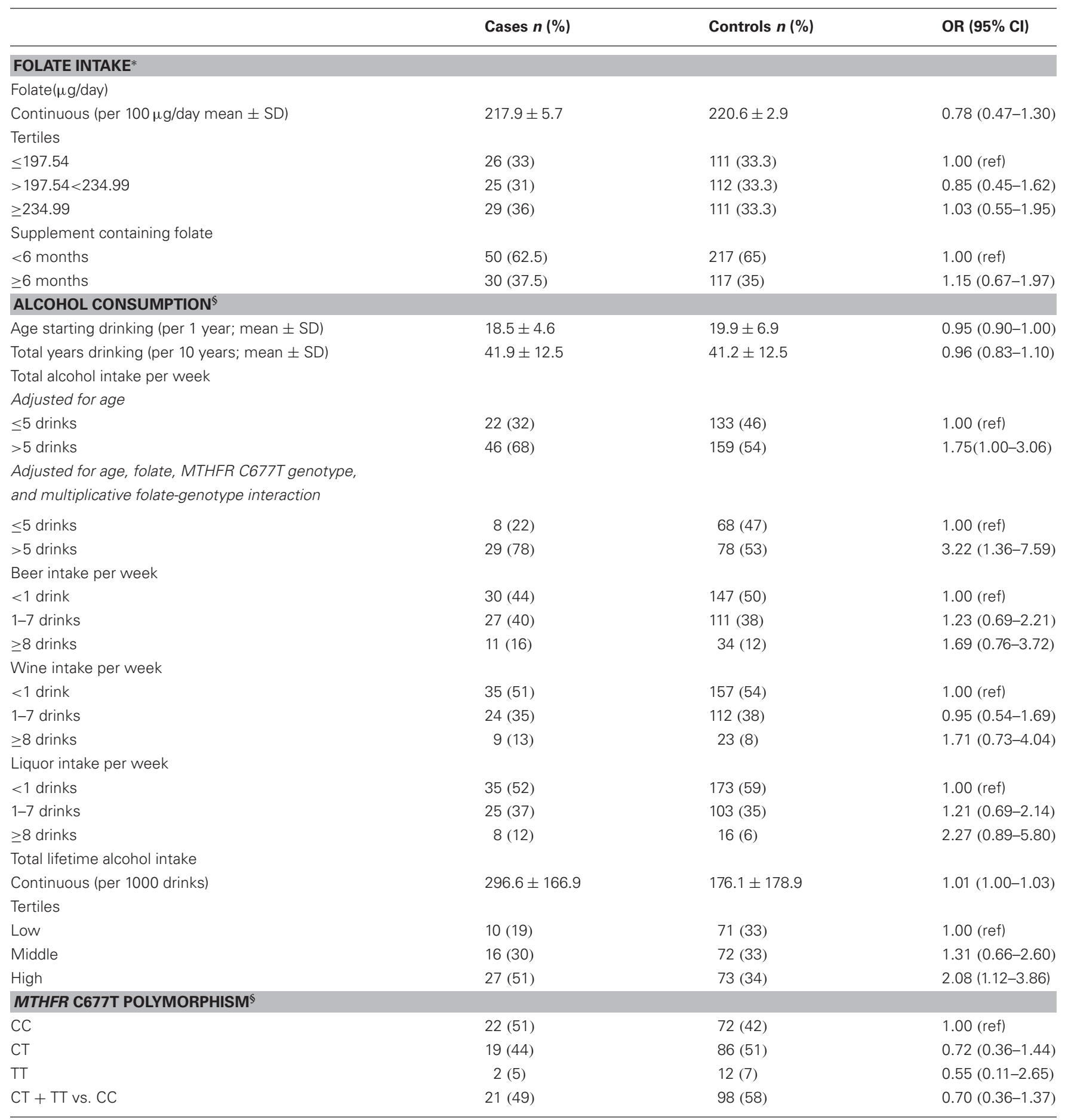

* ORs adjusted for age, personal income, marital status, physical activity as a teen, family history of breast cancer.

${ }^{\$}$ ORs adjusted for age.

p-values $<0.05$ were considered statistically significant.

wherein both high and low intakes may have deleterious effects at different stages in tumor progression (Stevens et al., 2006; Shannon et al., 2009; Collin et al., 2010a,b; Bistulfi et al., 2011).
The distribution of MTHFR genotypes among both cases and controls in our study was similar to the estimated population distribution of approximately 40,50 , and $10 \%$ prevalence for the CC, CT, and TT genotypes, respectively (Lathrop Stern et al., 
Table 3 | Folate intake, alcohol consumption, and prostate cancer risk (68 cases; 292 controls).

\begin{tabular}{lllll}
\hline $\begin{array}{l}\text { Folate } \\
\text { intake }\end{array}$ & $\begin{array}{l}\text { Alcohol } \\
\text { consumption }\end{array}$ & $\begin{array}{l}\text { Cases } \\
\boldsymbol{n}(\%)\end{array}$ & $\begin{array}{l}\text { Controls } \\
\boldsymbol{n}(\%)\end{array}$ & OR (95\% Cl)* \\
\hline Low & Low & $10(15)$ & $68(23)$ & $1.00($ ref $)$ \\
Low & High & $26(38)$ & $76(26)$ & $2.38(1.01-5.57)$ \\
High & Low & $12(18)$ & $65(22)$ & $1.16(0.44-3.09)$ \\
High & High & $20(29)$ & $83(28)$ & $1.67(0.70-4.01)$ \\
$\begin{array}{l}\text { p-interaction (multiplicative) } \\
\text { p-interaction (additive) }\end{array}$ & & & 0.80 \\
\hline
\end{tabular}

* ORs adjusted for age, personal income, marital status, physical activity as a teen, and family history of breast cancer.

$p$-values $<0.05$ were considered statistically significant.

Table 4 | Folate intake, MTHFR C677T genotype, and prostate cancer risk (43 cases, 170 controls).

\begin{tabular}{lllll}
\hline $\begin{array}{l}\text { Folate } \\
\text { intake }\end{array}$ & $\begin{array}{l}\text { MTHFR } \\
\text { genotype }\end{array}$ & $\begin{array}{l}\text { Cases } \\
\boldsymbol{n}(\%)\end{array}$ & $\begin{array}{l}\text { Controls } \\
\boldsymbol{n}(\%)\end{array}$ & OR (95\% Cl)* \\
\hline Low & CC & $11(26)$ & $33(19)$ & $1.00($ ref) \\
Low & CT + TT & $11(26)$ & $47(28)$ & $0.85(0.31-2.37)$ \\
High & CC & $11(26)$ & $39(23)$ & $1.06(0.37-3.03)$ \\
High & CT + TT & $10(23)$ & $51(30)$ & $0.73(0.26-2.08)$ \\
p-interaction (multiplicative) & & & 0.73 \\
p-interaction (additive) & & & 0.76
\end{tabular}

* ORs adjusted for age, personal income, marital status, physical activity as a teen and family history of breast cancer.

Table 5 | Alcohol consumption, MTHFR C677T genotype, and prostate cancer risk (37 cases; 146 controls).

\begin{tabular}{llcll}
\hline $\begin{array}{l}\text { Alcohol } \\
\text { consumption }\end{array}$ & $\begin{array}{l}\text { MTHFR } \\
\text { genotype }\end{array}$ & $\begin{array}{l}\text { Cases } \\
\boldsymbol{n}(\%)\end{array}$ & $\begin{array}{l}\text { Controls } \\
\boldsymbol{n}(\%)\end{array}$ & $\begin{array}{l}\text { Age-adjusted } \\
\text { OR (95\% Cl) }\end{array}$ \\
\hline Low & CC & $3(8)$ & $29(20)$ & $1.00($ ref) \\
Low & CT $+\mathrm{TT}$ & $5(14)$ & $39(27)$ & $1.25(0.28-5.65)$ \\
High & CC & $14(38)$ & $31(21)$ & $4.43(1.15-17.05)$ \\
High & CT $+\mathrm{TT}$ & $15(41)$ & $47(32)$ & $3.10(0.83-11.65)$ \\
p-interaction (multiplicative) & & & 0.51 \\
p-interaction (additive) & & & 0.58 \\
\hline
\end{tabular}

$p$-values $<0.05$ were considered statistically significant.

2000). Our results for the CT and TT MTHFR genotypes were null, although the ORs below one that we observed are consistent with one meta-analysis (Bai et al., 2009), while another shows no association between the MTHFR C677T polymorphism and prostate cancer risk (Collin et al., 2009).

Although this is a relatively small study that lacked power to detect most interactions, our finding of an over two-fold increase in prostate cancer risk for the interaction of low folate and high alcohol intake is consistent biologically with prostate carcinogenesis resulting from folate deficiency (Bistulfi et al., 2010). Other epidemiologic evidence for a folate-alcohol interaction is conflicting (Weinstein et al., 2003; Pelucchi et al., 2005; Stevens et al., 2006; Shannon et al., 2009). One study has examined a MTHFRfolate genotype interaction in prostate cancer, finding that the C677T polymorphism increases risk at high plasma folate levels (Van Guelpen et al., 2006). Our finding of an over four-fold increase in prostate cancer risk associated with alcohol consumption among men with the CC MTHFR genotype indicates a potentially strong gene-environment interaction between these two factors that has not been investigated in any other study we are aware of.

Strengths of this study include rigorous exclusion criteria and confirmation of all controls as having normal age-specific PSA levels. This decreased selection bias and ensured that the control group was not contaminated with latent prostate cancer. All men visited the same urologists in a single hospital and resided in the same geographic catchment area. Because all participants were recruited and completed the questionnaire prior to knowledge of disease status, differential recall error, and interviewer bias were avoided in this study. The food frequency questionnaire was highly detailed, reproducible, and valid, and was designed to represent average diet two years prior to study enrollment. The comprehensive statistical analysis of folate, B vitamins, and methionine, using energy-adjustment and three types of input variables also reduced the possibility of exposure misclassification. Questioning about average alcohol intake two years prior (relatively recent) reduced the possibility of recall error (Middleton Fillmore et al., 2009), and the comprehensive indicators of alcohol consumption reduced the possibility of exposure misclassification.

Dietary folate consumption among our study population was measured prior to 1998, when folate fortification of white wheat flour became mandatory in Canada and the United States. Dietary folate consumption and folate status of our study population are likely lower than that of the more recent general Canadian and US populations (Baily et al., 2010; Colapinto et al., 2011). Our results are relevant since assessing lower folate consumption in these countries may be more difficult now because of fortification. However, low variation in our observed range of folate intakes may have limited our ability to detect both main effects and interactions with folate, since folate intake in the first and third tertiles differed by only $38 \mu \mathrm{g}$ in our study.

In summary, we found that alcohol consumption is associated with increased prostate cancer risk, with higher risk among men with low folate intake and among men with the CC MTHFR genotype. Taking into account potential combined effects and interactions is important for future studies, and may in part explain inconsistent findings to date. Future work should also capture a greater range of folate intakes to determine the true role of folate in prostate carcinogenesis, and whether this is role is dualistic in nature, to inform public policy regarding folate fortification.

\section{ACKNOWLEDGMENTS}

We would like to thank the following people for their contributions to this work: study participants, and Drs. James W. L. Wilson, Jeremy P. W. Heaton, J. Curtis Nickel, Andrew 
MacNeily, Alvaro Morales, Pamela Brown, and Linda Levesque, Ms. Catherine Elliott, and Ms. Caroline Andison. This research was supported by the Canadian Institutes of Health Research (CIHR), and was part of a Master of Science thesis by

\section{REFERENCES}

Agriculture and Agri-Food Canada, and Food Value Chain Bureau. (2004). Retail Sales Data 1996. Ottawa, ON: Agriculture and AgriFood Canada.

Agriculture and Agri-Food Canada, and Statistics Canada. (2010). Canada Food Stats 1996. Ottawa, ON: Statistics Canada. 23F0001XCB.

Aronson, K. J., Wilson, J. W. L., Hamel, M., Diarsvitri, W., Fan, W., Woolcott, C., Heaton, J. P. W., Nickel, J. C., MacNeily, A., and Morales, A. (2010). Plasma organochlorine levels and prostate cancer risk. J. Expo. Sci. Eviron. Epidemiol. 20, 434-445.

Bai, J.-L., Zheng, M.-H., Xia, X., Ter-Minassian, M., Chen, Y.-P., and Chen, F. (2009). MTHFR C677T polymorphism contributes to prostate cancer risk among Caucasians: a meta-analysis of 3511 cases and 2761 controls. Eur. J. Cancer 45, 1443-1449.

Baily, R. L., Dodd, K. W., Gahche, J. J., Dwyer, J. T., McDowell, M. A., Yetley, E. A., Sempos, C. A., Burt, V. L., Radimer, K. L., and Picciano, M. F. (2010). Total folate and folic acid intake from foods and dietary supplements in the United States: 2003-2006. Am. J. Clin. Nutr. 91, 231-237.

Beilby, J., Ambrosini, G. L., Rossi, E., de Klerk, N. H., and Musk, A. W. (2010). Serum levels of folate, lycopene, $\beta$-carotene, retinol and vitamin $\mathrm{E}$ and prostate cancer risk. Eur. J. Clin. Nutr. 64, 1235-1238.

Bistulfi, G., Foster, B. A., Karasik, E., Gillard, B. M., Miecznikowski, J., Dhiman, V. K., and Smiraglia, D. J. (2011). Dietary folate deficiency blocks prostate cancer progression in the TRAMP model. Cancer Prev. Res. (Phila.) 4, 1825-1834.

Bistulfi, G., VanDette, K., Matsui, S.I., and Smiraglia, D. J. (2010). Mild folate deficiency induces genetic and epigenetic instability and phenotype changes in prostate cancer cells. BMC Biol. 8, 6 .

Byers, T., Marshall, J., Fiedler, R., Zielezny, M., and Graham, S. (1985). Assessing nutrient intake with an abbreviated dietary interview. Am. J. Epidemiol. 122, 41-50.

Cai, D., Ning, L., Pan, C., Liu, C., Bu, R., Chen, X., Wang, K.,
Cheng, Y., and $\mathrm{Wu}, \mathrm{B}$. (2010). Association of polymorphisms in folate metabolic genes and prostate cancer risk: a case-control study in a Chinese population. J. Genet. 89 , 263-267.

Colapinto, C. K., O'Connor, D. L., and Tremblay, M. S. (2011). Folate status of the population in the Canadian Health Measures Survey. CMAJ 183, E100-E106.

Collin, S. M., Metcalfe, C., Refsum, H., Lewis, S. J., Smith, G. D., Cox, A., Davis, M., Marsden, G., Johnston, C., Lane, J. A., Donovan, J. L., Hamdy, F. C., Smith, A. D., and Martin, R. M. (2010a). Associations of folate, vitamin $\mathrm{B}_{12}$, homocysteine, and folate-pathway polymorphisms with prostatespecific antigen velocity in men with localized prostate cancer. Cancer Epidemiol. Biomarkers Prev. 19, 2833-2888.

Collin, S. M., Metcalfe, C., Refsum, H., Lewis, S. J., Zuccolo, L., Smith, G. D., Chen, L., Harris, R., Davis, M., Marsden, G., Johnston, C., Lane, J. A., Ebbing, M., Bonaa, K. H., Nygard, O., Ueland, P. M., Grau, M. V., Baron, J. A., Donovan, J. L., Neal, D. E., Hamdy, F. C., Smith, A. D., and Martin, R. M. (2010b). Circulating folate, vitamin $B_{12}$, homocysteine, vitamin $\mathrm{B}_{12}$ transport proteins, and risk of prostate cancer: a case-control study, systematic review, and meta-analysis. Cancer Epidemiol. Biomarkers Prev. 19, 1632-1642.

Collin, S. M., Metcalfe, C., Zuccolo, L., Lewis, S. J., Chen, L., Cox, A. Davis, M., Lane, J. A., Donovan, J., Smith, G. D., Neal, D. E., Gudmundsson, J., Sulem, P., Rafnar, T., Benediktsdottir, K. R., Eeles, R. A., Guy, M., Kote-Jarai, Z., UK Genetic Prostate Cancer Study Group, Morrison, J., Al Olama, A. A., Stefansson, K., Easton, D. F., and Martin, R. M. (2009). Association of folate-pathway gene polymorphisms with the risk of prostate cancer: a population-based nested case-control study, systematic review, and meta-analysis. Cancer Epidemiol. Biomarkers Prev. 18, 2528-2539.

Dennis, L. (2000). Meta-analysis for combining relative risks of alcohol consumption and prostate cancer. Prostate 42, 56-66.

Heather Limburg, who was supported by the Queen's University Terry Fox Foundation Training Program in Transdisciplinary Cancer Research in Partnership with CIHR, and Empire Life of Kingston, ON.

El-Sammak, M., Kandil, M., El-Hifni, S., Hosni, R., and Ragab, M. (2004). Elevated plasma homocysteine is positively associated with age independent of C677T mutation of the methylenetetrahydrofolate reductase gene in selected Egyptian subjects. Int. J. Med. Sci. 1, 181-192.

Fairfield, K., and Fletcher, R. (2002) Vitamins for chronic disease prevention in adults. JAMA 287, 3116-3126.

Ferlay, J., Shin, H. R., Bray, F., Forman, D., Mathers, C., and Parkin, D. M. (2010). GLOBOCAN (2008) v1.2. GLOBOCAN Cancer Fact Sheets: Prostate Cancer: IARC CancerBase No. 10. (Lyon, France: International Agency for Research on Cancer; 2010). Available online at: http://globocan.iarc.fr [Accessed July 4, 2012].

Figueiredo, J. C., Grau, M. V., Haile, R. W., Sandler, R. S., Summers, R. W., Bresalier, R. S., Burke, C. A., McKeown-Eyssen, G. E., and Baron, J. A. (2009). Folic acid and risk of prostate cancer: results from a randomized clinical trial. J. Natl. Cancer Inst. 101, 432-435.

Frosst, P., Blom, H. J., Goyette, M P., Sheppard, C. A., Matthews, R. G., Boers, G. J. H., den Heijer, M. Kluijtmans, L. A. J., van den Heuve, L. P., and Rozen, R. (1995). A candidate genetic risk factor for vascular disease: a common mutation in methylenetetrahydrofolate reductase. Nat. Genet. 10, 111-113.

Hultdin, J., Van Guelpen, B., Bergh, A., Hallmans, G., and Stattin, P. (2005). Plasma folate, vitamin B12, and homocysteine and prostate cancer risk: a prospective study. Int. J. Cancer 113, 819-824.

International Agency for Research on Cancer, World Health Organization. (2008). World Cancer Report 2008. Lyon, France: IARC Press.

Johansson, M., Appleby, P. N., Allen, N. E., Travis, R. C., Roddam, A. W., Egevad, L., Jenab, M., Rinaldi, S., Kiemeney, L. A., Bueno-deMesquita, H. B., Vollset, S. E. Ueland, P. M., Sanchez, M. J., Quiros, J. R., Gonzalez, C. A., Larranaga, N., Chirlague, M. D., Ardanaz, E., Sieri, S., Palli, D. Vineis, P., Tumino, R., Linseisen, J., Kaaks, R., Boeing, R., Pischon, T., Psaltopoulou, T., Trichopoulou, T., Trichopoulos, D., Khaw, K. T.
Bingham, S., Hallmans, G., Riboli, E., Stattin, P., and Key, T. J. (2008). Circulating concentrations of folate and vitamin $B_{12}$ in relation to prostate cancer risk: results from the European Prospective Investigation into Cancer and Nutrition Study. Cancer Epidemiol. Biomarkers Prev. 17, 279-285.

Kim, Y. (1999). Folate and cancer prevention: a new medical application of folate beyond hyperhomocysteinemia and neural tube defects. Nutr. Rev. 57, 314-321.

Kote-Jarai, J., Al Olama, A., Giles, G. G., Severi, G., Schleutker, J., Weischer, M., Campa, D., Riboli, E., Key, T., Gronberg, H., Hunter, D. J., Kraft, P., Thun, M. J., Ingles, S., Chanock, S., Albanes, D., Hayes, R. B., Neal, D. E., Hamdy, F. C., Donovan, J. L., Pharoah, P., Schumacher, F., Henderson, B. E., Stanford, J. L., Ostrander, E. A., Dalsgaard Sorensen, K., Dörk, T., Andriole, G., Dickinson, J. L., Cybulski, C., Lubinski, J., Spurdle, A., Clements, J. A., Chambers, S., Aitken, J., Gardiner, R. A. F., Thibodeau, S. N., Schaid, D., John, E. M., Maier, C., Vogel, W., Cooney, K. A., Park, J. Y., Cannon-Albright, L., Brenner, H., Habuchi, T., Zhang, H.-W., Lu, Y.-J., Kaneva, R., Muir, K., Benlloch, S., Leongamornlert, D. A., Saunders, E. J., Tymrakiewicz, M., Mahmud, N., Guy, M., O’Brien, L. T., Wilkinson, R. A., Hall, A. L., Sawyer, E. J., Dadaev, T., Morrison, J., Dearnaley, D. P., Horwich, A., Huddart, R. A., Khoo, V. S., Parker, C. C., Van As, N., Woodhouse, C. J., Thompson, A., Christmas, T., Ogden, C., Cooper, C. S., Lophatonanon, A., Southey, M. C., Hopper, J. L., English, D. R., Wahlfors, T., Tammela, T. L. J., Klarskov, P., Børge, G., Nordestgaard, B. G., Røder, M. A., Tybjærg-Hansen, A., Bojesen, S. E., Travis, R., Canzian, F., Kaaks, R., Wiklund, F., Aly, M., Lindstrom, S., Diver, W. R., Gapstur, S., Stern, M. C., Corral, R., Virtamo, J., Cox, A., Haiman, C. A., Le Marchand, L., FitzGerald, L., Kolb, S., Kwon, E. M., Karyadi, D. M., Falck Ørntoft, T., Borre, M., Meyer, A., Serth, J., Yeager, M., Berndt, S. I., Marthick, J. R., Patterson, B., Wokolorczyk, D., Batra, J., Lose, F., McDonnell, S. K. Joshi, A. D., Shahabi, A., Rinckleb, 
A. E., Ray, A., Sellers, T. A., Lin, H.-Y., Stephenson, R. A., Farnham, J., Muller, H., Rothenbacher, D., Tsuchiya, N., Narita, S., Cao, G.W., Slavov, C., Mitev, V., The UK Genetic Prostate Cancer Study Collaborators/British Association of Urological Surgeons' Section of Oncology, The UK ProtecT Study Collaborators, The Australian Prostate Cancer BioResource, The PRACTICAL Consortium, Easton, D. F., and Eeles, R. A. (2011). Seven prostate cancer susceptibility loci identified by a multi-stage genomewide association study. Nat. Genet. $43,785-792$

Lathrop Stern, L., Mason, J. B., Selbub, J., and Choi, S.-W. (2000). Genomic DNA hypomethylation, a characteristic of most cancers, in present in peripheral leukocytes of individuals who are homozygous for the C677T polymorphism in the methylenetetra-hydrofolate reductase gene. Cancer Epidemiol. Biomarkers Prev. 9, 849-853.

Lewis, C. M. (2002). Genetic association studies: design, analysis, and interpretation. Brief. Bioinform. 3, 146-153.

Littell, R. C., Stroup, W. W., and Freund, R. J., (2002). SAS ${ }^{\circledR}$ for Linear Models, 4th Edn. Cary, NC: SAS Institute, Inc.

Lucock, M., and Yates, Z. (2009). Folic acid fortification: a doubleedged sword. Curr. Opin. Clin. Nutr. Metab. Care 12, 555-564.

Middleton Fillmore, K., Chikritzhs, T., Stockwell, T., Bostrom, A., and Pascal, R. (2009). Alcohol use and prostate cancer: a meta-analysis. Mol. Nutr. Food Res. 53, 240-255.

National Cancer Institute. (2004). PDQ ${ }^{\circledR}$ Genetics of Prostate Cancer. Last modified 2010 Nov 23. Available online at: http:// www.nci.nih.gov/cancertopics/pdq/ genetics/prostate [Accessed Jan 6, 2011].

Neuhouser, M. L., Nijhout, H. F., Gregory, J. F., Reed, M. C., James, S. J., Liu, A., Shane, B., and Ulrich, C. M. (2011). Mathematical modelling predicts the effect of folate deficiency and excess on cancer related biomarkers. Cancer Epidemiol. Biomarkers Prev. 20, 1912-1917.

Nutrition Research Division, and Health Canada. (2001). Canadian Nutrient File, 2001b. Ottawa, ON: Health Canada.

Nutrition Research Division, and Health Canada. (2007). Canadian
Nutrient File, 2007b. Ottawa, ON: Health Canada.

Pelucchi, C., Galeone, C., Talamini, R., Negri, E., Parpinel, M., Franceschi, S., Montella, M., and La Vecchia, C. (2005). Dietary folate and risk of prostate cancer in Italy. Cancer Epidemiol. Biomarkers Prev. 14, 944-948.

Qi, X., Ma, X., Yang, X., Fan, L., Zhang, Y., Zhang, F., Chen, L., Zhou, Y., and Jiang, J. (2010). Methylenetetrahydrofolate reductase polymorphisms and breast cancer risk: a meta-analysis from 41 studies with 16, 480 cases and 22, 388 controls. Breast Cancer Res. Treat. 123, 499-506.

Rossi, E., Hung, J., Beilby, J. P., Knuiman, M. W., Divitini, M. L. and Bartholomew, H. (2006). Folate levels and cancer morbidity and mortality: prospective cohort study from Busselton, Western Australia. Ann. Epidemiol. 16, 206-212.

Rothman, K. J., and Greenland, S. (1998). Modern Epidemiology, 2nd Edn. Philadelphia, PA: LippincottRaven.

Schumacher, F. R., Berndt, S. I., Siddiq, A., Jacobs, K. B., Wang, Z., Lindstrom, S., Stevens, V. L., Chen, C., Mondul, A. M., Travis, R. M., Stram, D. O., Eeles, R. A., Easton, D. F., Giles, G., Hopper, J. L., Neal, D. E., Hamdy, F. C., Donovan, J. L., Muir, K., Amin Al Olama, A., Kote-Jarai, Z., Guy, M., Severi, G., Gronberg, H., Isaacs, W. B., Karlsson, R., Wiklund, F., Xu, J., Allen, N. E., Andriole, G. L., Barricarte, A., Boeing, H., Buenode-Mesquita, H. B., Crawford, E. D., Diver, W. R., Gonzalez, C. A. Gaziano, J. M., Giovannucci, E. L., Johansson, M., Le Marchand, L., Ma, J., Sieri, S., Stattin, P., Stampfer, M. J., Tjonneland, A., Vineis, P., Virtamo, J., Vogel, U., Weinstein, S. J., Yeager, M., Thun, M. J., Kolonel, L. N., Henderson, B. E., Albanes, D., Hayes, R. B., Spencer Feigelson, H., Riboli, E., Hunter, D. J., Chanock, S. J., Haiman, C. A., and Kraft, P. (2011). Genome-wide association study identifies new prostate cancer susceptibility loci. Hum. Mol. Genet. 20, 3867-3875.

Shannon, J., Phoutrides, E., Palma, A., Farris, P., Peters, L., Forester, A., Tillotson, C. J., and Garzotto, M. (2009). Folate intake and prostate cancer risk: a case-control study. Nutr. Cancer 61, 617-628.

Stevens, V. L., Rodriguez, C., Pavluck, A. L., McCollough, M. L., Thun,
M. J., and Calle, E. E. (2006) Folate nutrition and prostate cancer incidence in a large cohort of US men. Am. J. Epidemiol. 163 989-996.

Thomas, G., Jacobs, K. B., Yeager M., Kraft, P., Wacholder, S., Orr, N., Yu, K., Chattergee, N., Welch, R., Hutchinson, A., Crenshaw, A., Cancel-Tassin, G., Staats, B. J., Wang, Z., Gonzalez-Bosquet, J., Fang, J., Deng, X., Berndt, S. I., Calle, E. E., Spencer Feigelson, H., Thun, M. J., Rodriguez, C. Albanes, D., Virtamo, J., Weinstein, S., Schumacher, F. R., Giovannucci, E., Willett, W. C., Cussenot, O., Valeri, A., Andriole, G. L., Crawford, E. D., Tucker, M., Gerhard, D. S., Fraumeni, J. F. Jr., Hoover, R., Hayes, R. B., Hunter, D. J., and Chanock, S. J. (2008). Multiple loci identified in a genome-wide association study of prostate cancer. Nat. Genet. 40, 310-315.

Tiaoli, E., Garza, M. A., Ahn, Y. O., Bishop, D. T., Bost, J., Chen, K., Gemignani, F., Keku, T., Lima, C. S., Le Marchand, L., Matsuo, K., Moreno, V., Plaschke, J., Pufulete, M., Thomas, S. B., Toffoli, G. Wolf, C. R., Moore, C. G., and Little, J. (2009). Meta- and pooled analysis of the methylenetetrahydrofolate reductase (MTHFR) C677T polymorphism and colorectal cancer: a HuGE-GSEC review. Am. J. Epidemiol. 170, 1207-1221.

Tomaszewski, J. J., Cummings, J. L. Parwani, A. V., Dhir, R., Mason, J. B., Nelson, J. B., Bacich, D. J., and O'Keefe, D. S. (2011). Increased cancer cell proliferation in prostate cancer patients with high levels of serum folate. Prostate 71, 1287-1293.

Van Guelpen, B. R., Wiren, S. M., Bergh, A. R. J., Hallmans, G., Stattin, P. E., and Hultdin, J. (2006) Polymorphisms of methylenetetrahydrofolate reductase and the risk of prostate cancer-a nested case-control study. Eur. J. Cancer $15,46-50$.

Vlajinac, H. D., Marinkovic, J. M., Ilic, M. D., and Kocev, N. I. (1997). Diet and prostate cancer: a case-control study. Eur. J. Cancer 33, 101-107.

Walker, M., Aronson, K. J., King, W. Wilson, J. W. L., Fan, W., Heaton, J. P. W., MacNeily, A., Nickel, J. C., and Morales, A. (2005). Dietary patterns and risk of prostate cancer in Ontario, Canada. Int. J. Cancer 116, 592-598.
Weinstein, S. J., Hartman, T. J., Stolzenberg-Solomon, R., Pietinen, P., Barrett, M. J., Taylor, P. R., Virtamo, J., and Albanes, D. (2003). Null association between prostate cancer and serum folate, vitamin $\mathrm{B}_{6}$, vitamin $\mathrm{B}_{12}$, and homocysteine Cancer Epidemiol. Biomarkers Prev. 12, 1271-1272.

Weinstein, S. J., Stolzenberg-Solomon, R., Piertinen, P., Taylor, P. R. Virtamo, J., and Albanes, D. (2006). Dietary factors of one-carbon metabolism and prostate cancer risk. Am. J. Clin. Nutr. 84, 929-935.

Willett, W. (1998). Nutritional Epidemiology. New York, NY: Oxford University Press.

Willett, W., Sampson, L., Browne, M., Stampfer, M., Rosner, B. Hennekens, C. H., and Speizer F. E. (1988). The use of a selfadministered to assess diet four years in the past. Am. J. Epidemiol. $127,188-189$.

Zhang, Y., Coogan, P., Palmer, J. R., Strom, B. L., and Rosenberg, L. (2009). Vitamin and mineral use and risk of prostate cancer: the case-control surveillance study. Cancer Causes Control 20, 691-669.

Conflict of Interest Statement: The authors declare that this research was conducted in the absence of any commercial or financial relationships that could be construed as a potential conflict of interest.

Received: 17 May 2012; accepted: 27 July 2012; published online: 14 August 2012. Citation: Kobayashi LC, Limburg H, Miao Q, Woolcott C, Bedard LL, Massey TE and Aronson KJ (2012) Folate intake, alcohol consumption, and the methylenetetrahydrofolate reductase (MTHFR) C677T gene polymorphism: influence on prostate cancer risk and interactions. Front. Oncol. 2:100. doi: $10.3389 /$ fonc. 2012.00100

This article was submitted to Frontiers in Cancer Epidemiology and Prevention, a specialty of Frontiers in Oncology. Copyright (๑) 2012 Kobayashi, Limburg. Miao, Woolcott, Bedard, Massey and Aronson. This is an open-access article distributed under the terms of the Creative Commons Attribution License, which permits use, distribution and reproduction in other forums, provided the original authors and source are credited and subject to any copyright notices concerning any third-party graphics etc. 